\title{
An energy-efficient smart home for new cities in Egypt
}

\author{
M. M. Mourad ${ }^{1}$, A. H. H. Ali ${ }^{1}$, S. Ookawara ${ }^{2}$, \\ A. K. Abdel-Rahman ${ }^{1} \&$ N. M. Abdelkariem ${ }^{3}$ \\ ${ }^{1}$ Department of Energy Resources Engineering, \\ Egypt-Japan University of Science and Technology, Egypt \\ ${ }^{2}$ Department of Chemical Engineering, \\ Tokyo Institute of Technology, Japan \\ ${ }^{3}$ Department of Architectural Engineering, Assuit University, Egypt
}

\begin{abstract}
The rapid growth of energy use, worldwide, has raised concerns over problems of energy supply. Residential home energy consumption is now an important component of total energy. The term 'smart home' has emerged as the keyword for such automated dwellings, by letting the system decide on an environmentally friendly time to consume energy. The major shift in the vision of sustainable efficient homes in cities is the potential of buildings to produce energy. In this study, an efficient design of a single family home with all passive architectural systems will carried out. This will be followed by the calculation of energies as a function of yearly distribution that is required for this home. This study aims at designing an energy-efficient smart home with renewable energy utilizations during the early stages of planning of new societies in the Egyptian desert. A prototype house for single-family detached houses of about $240 \mathrm{~m}^{2}$ on two floors, each floor comprising about $120 \mathrm{~m}^{2}$, with efficient utilization of the renewable energies technologies is proposed. In order to achieve the above objective, this paper presents a review for energy efficiency in Egypt, and a detailed analysis of the efficient renewable energy technologies used in smart homes. The present study showed that the smart house for single-family detached houses in new societies in Egypt could be efficient and save about $20 \%$ of the home energy bill.

Keywords: Egyptian new cities, hot arid areas, renewable energy, efficient homes, renewable energy technologies.
\end{abstract}




\section{Introduction of energy efficiency in Egypt}

Energy efficiency and comfort conditions in buildings are some of the crucial concerns in design and decision making phase for many architectural design process in the last few decades. With the present energy crises in Egypt there is a current focus on the development of energy sensitive design building approaches (Dabaieh [1]). Although energy efficiency had not taken a prominent role in Egypt's past energy strategy, it has now become a high priority. The government has now arrived at the conclusion that energy efficiency should be pursued aggressively (AfDB [2]). Electricity consumption in Egypt is increasing rapidly. According to government figures, Egypt's two major end-users of electricity are the residential sector and the industrial sector. The residential sector experienced one of the most rapid average annual growth by 7.5 percent over the last five years (Sawin and Mastny [3]).

However, buildings can be designed to meet occupant's need for thermal and visual comfort at reduced levels of energy and resources consumption. Energy resource efficiency in new constructions can be affected by adopting an integrated approach to building design. The primary steps in this approach would be incorporate solar passive techniques in a building design to minimise load on conventional systems (heating, cooling, ventilation and lighting), also design energy-efficient lighting and HVAC systems (heating, ventilation and airconditioning), and using renewable energy systems (solar photovoltaic systems/ solar water heating systems) to meet part of building load (Majumdar [4]).

The recent state of art in Egypt concerned with energy efficiency in residential buildings in which they are the major consumer of energy in the country where $45 \%$ of the population live in urban areas. In 2010 , the residential building sector consumed more than $47 \%$ of the total nationally generated electricity. Approximately 11 million tons of oil equivalents (Mtoe) of energy were consumed by approximately 20 million apartments (Attia et al. [5]). Artificial lighting is estimated to account about $40 \%$ of the electricity used in the residential sector and $35 \%$ of the electricity used for HVAC system. A significant increase in electricity demand is expected over the next few years with a growth rate over $10 \%$ (Hanna [6]).

To improve the energy efficiency in residential buildings, an Egyptian energy Building Code had been developed for new residential buildings (HBRC [7]). In January 2009, a major step was taken by establishing the Egyptian Green Building Council (Egypt-GBC). Egyptian stakeholders and government officials have looked for methods to reduce power consumption and $\mathrm{CO}_{2}$ emissions. Within the building sector, efforts at enforcement have been nonexistent. Proposals to improve performance in this area have been put forward but interest and manpower have been lacking. While many people are examining this dilemma others are searching for alternative systems to address the same issues and increase awareness regarding their importance (Egypt-GBC [8]).

The Government of Egypt (GoE) has prepared a National Energy efficiency plan and has set up an in tier energy conservation coordination group to coordinate activities of energy consumers and supplies in promoting more 
efficient use of energy. The current activities are focusing on increasing use of compact fluorescent lamps (CFLs), improving energy efficiency in street lighting, public buildings, and scaling up solar water heating (SWH) (NREA [9]). The Supreme Energy Council of Energy which represents the Technical Cabinet of Ministers in Egypt supports efforts to increase the potential of Energy Efficiency use and encourage new projects to utilize Renewable Energy Technology particularly wind, solar and increase the efficiency of hydro-energy. The potential of Renewable Energy in 2020 is estimated to be $20 \%$ of the total Energy uses in Egypt mainly wind and hydropower (Hanna [10]).

In the last decade, the term 'smart home' has emerged as the keyword for such automated dwellings. The vision is a house populated by a multitude of devices (actuators and sensors) that cooperate in an intelligent way to control different domains of the home such as lighting/shading or heating/ventilation/airconditioning. Also home appliances and consumer electronics are more and more considered for integration into these automation systems (YSCP [11]) as shown in Fig. 1. By letting the system decide on an environmentally friendly time to consume energy, the ecological footprint of each resident can be significantly reduced. Such a system could also function as the central point to integrate demand side management applications into the house, e.g., by shifting energy intensive operations to a more convenient point in time.

This allows for example considering cheap excess energy becoming available from energy providers (Kofler et al. [12]). Based on the systems requirements, the proposed system hardware should have two basic building blocks (Al-Ali et $a l$. [13]). These building blocks consist of a solar cell, charge converter, battery, DC/AC inverter, energy meter and global system for mobile communications (GSM) modem. The house gets its power from two sources namely; the power grid and the solar cell. The solar cell energy is stored in a battery and then inverted to $\mathrm{AC}$ power.

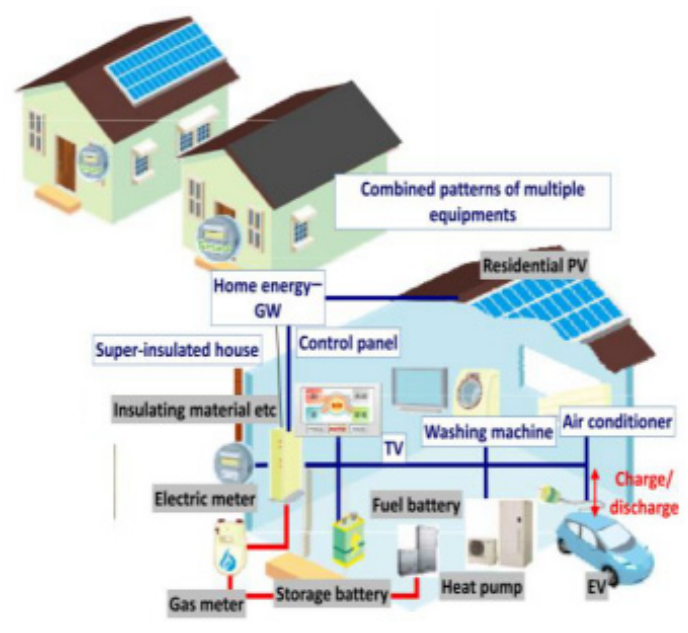

Figure 1: Concept of the smart home energy management system (YSCP [11]). 


\section{Efficient renewable energy technologies used in smart homes}

Renewable energy resources used in smart homes are solar and wind energies, in which both recourses has efficient technologies in the market to provide the home energy needs for utilities and comfort condition.

\subsection{Solar energy technology}

Solar energy technologies are considering the energy for the future. Such technologies are hoped to be the main energy supplier in desert areas in the nearest future, to provide homes by electricity, heat and play a role through solar chimney for supplying cold air is summer time. Photovlotice (PV) system is the technology that generates electrical power from solar energy using semiconductors when they are illuminated by solar radation photons. The architect or designer should utilize all visible opportunities to integrate PV into the building design in a highly aesthetic way (Reijenga [14]). Modularity is perhaps the single most attractive feature of this technology (Huacuz and Gunaratne [15]). Photovoltaic (PV) cells suffer from a drop in efficiency with the rise in temperature due to increased resistance. Hybrid Photovoltaic thermal (PV/T ) systems that converts solar radiation into thermal and electrical energy. Such systems can be engineered to carry heat away from the PV cells thereby cooling the cells and thus improving their efficiency by lowering resistance (TES solar water [16]).

\subsection{Wind energy technology}

Wind energy technologies compared with other renewable energy technologies, is the closest to being competitive with fossil-based systems. These facts should dispel any uncertainty about the future role of wind in the energy scenarios of the twenty-first century. Small-scale wind generation that can operate as embedded generation in buildings is the most interesting developments that have taken place. They are mainly confined to the domestic level and are often used to charge batteries. Energy production costs are less expensive at those good wind sites in terms of installed cost per kilowatt than PV which makes it an attractive proposition as a building integrated power source (Aziz and Elmassah [17]). The system of wind catcher earth air tunnels has a daily and annual temperature fluctuations decrease with the increase in depth of air tunnels below the ground surface. At a depth of about $4 \mathrm{~m}$ below ground, the temperature inside the earth remains nearly constant round the year and is nearly equal to the annual average temperature of the place (Bioclimatic Architecture [18]). A tunnel in the form of a pipe or otherwise embedded at a depth of about $4 \mathrm{~m}$ below the ground will acquire the same temperature as the surrounding earth at its surface. Therefore, the ambient air ventilated through this tunnel will get cooled in summer and warmed in winter and this air can be used for cooling in summer and heating in winter (wordpress [19]). 


\section{Suggested prototype energy efficient-smart house}

As this study aim is to design energy efficient home with maximum possible renewable energy utilizations at early stage of planning of new societies in Egyptian desert, therefore, a prototype house for single-family detached houses of $240 \mathrm{~m}^{2}$ on two floors, each floor of $120 \mathrm{~m}^{2}$ (as shown in Figs. 2 and 3). The proposed prototype is making use of the maximum possible utilization of the available renewable energies resources with high efficiency technologies of the house is sited (as shown in Figs. 4 and 5). This suggested prototype house is design for new single-family detached houses for Egyptian new cities which consider as a key for Egypt future in the habitation of people in new towns.

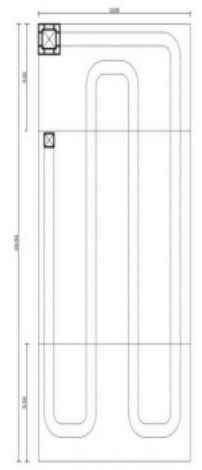

under ground floor plan

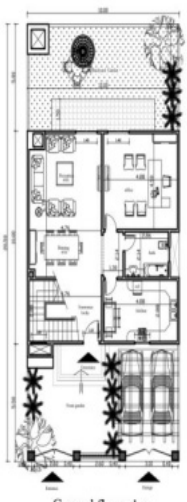

Ground floor plan

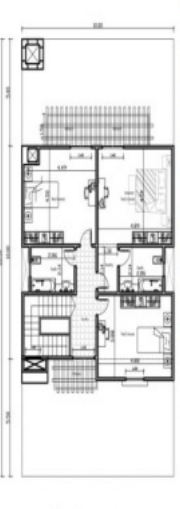

First floor plan

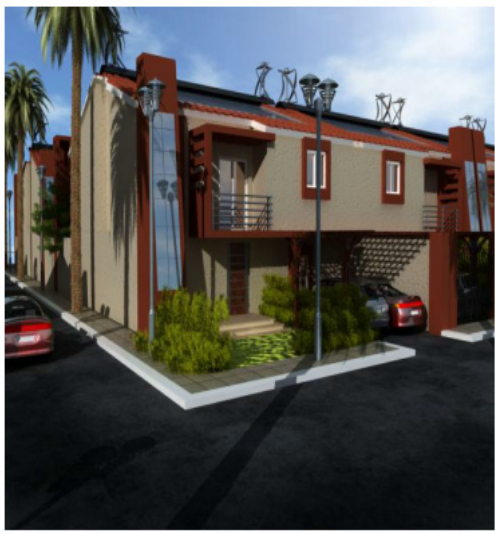

Figure 2: Suggested prototype house for single-family detached houses planes and perspectives

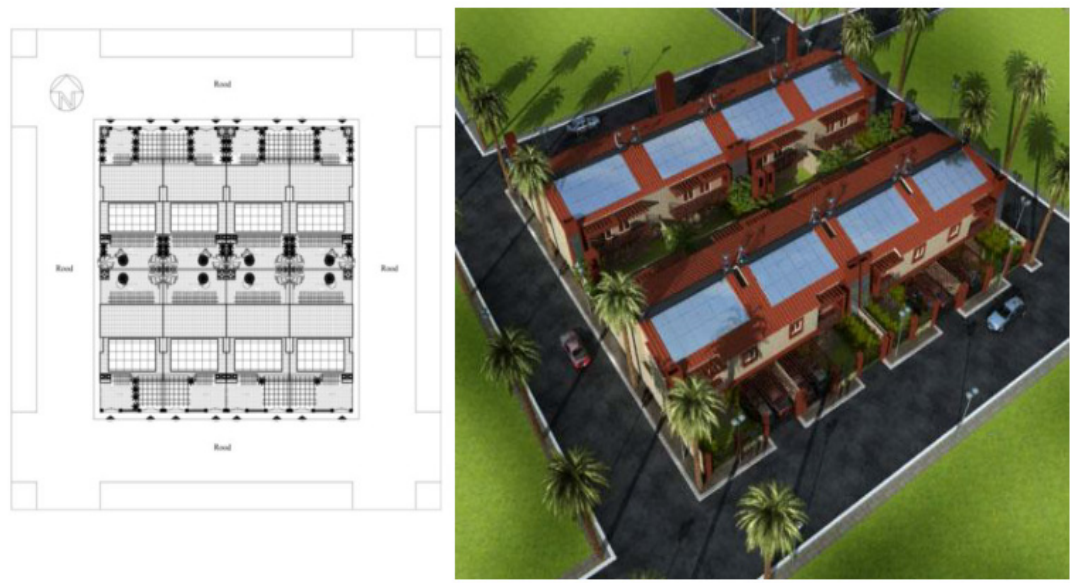

Figure 3: Suggested layout for prototype house mass plane and perspectives. 


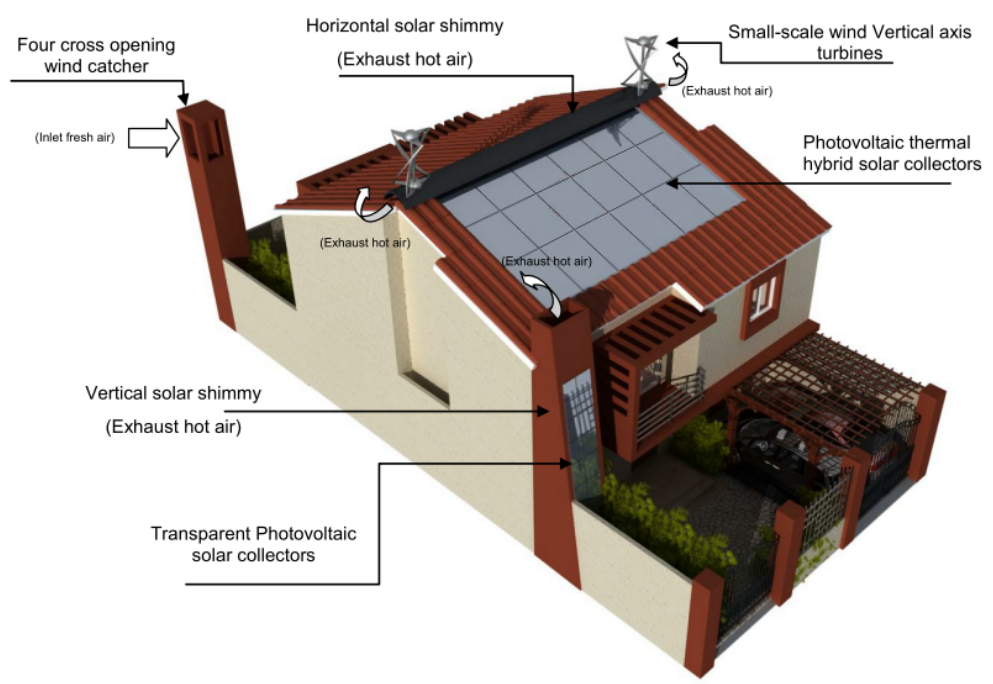

Figure 4: Renewable energy technologies used in a suggested prototype smart house.

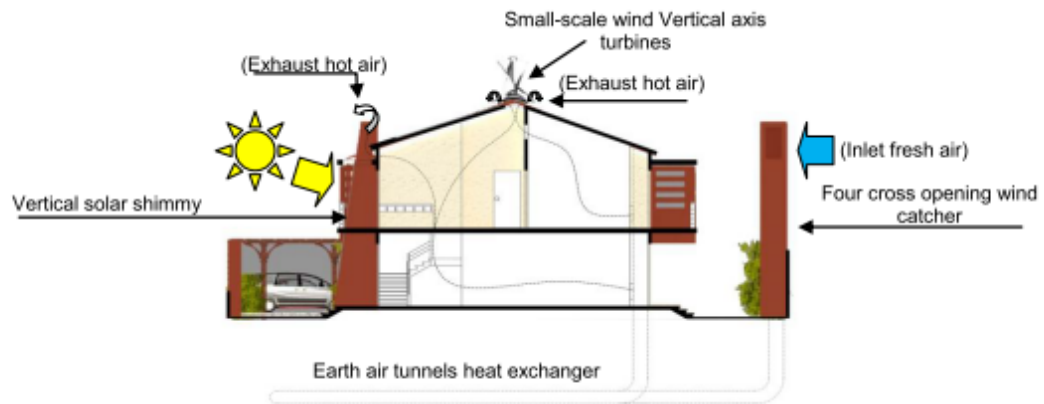

Figure 5: Suggested prototype smart house cross section.

In the suggested house, it is proposed to use four cross opening wind catcher earth air tunnels as a source for fresh air cooling supply, also a horizontal and vertical solar shimmy collector for hot air exhaust. Also using a hybrid Photovoltaic - thermal solar collectors as a source for electric power and solar thermal energies. The electricity flows into an inverter for use in the building or export to the grid as per a standard PV configuration. The temperature is regulated via a control sensor and the coolant is transferred using a pump to a heat exchanger which heats water in a storage tank for use in the hot water, heating and optional cooling systems. The system provides hot water for any kind of usage such as sanitary use, domestic applications (such as dish and clothes washing) and any other required usage. The heating output can be used for room heating and cooling as well as pool heating and other heating 
equipment. Moreover, it's proposed using small-scale wind vertical axis turbines, as a source for electric power also. Small-scale wind vertical axis turbines are particularly suited to urban situations and to being integrated into buildings. Presently, there are several versions of vertical axis machines available in the market. It is suggested to use the helical turbine which is the most common vertical axis machine. In that instance it is mounted on a tower but it can also be side-hung on a building. This technology can generate power from $1 \mathrm{~kW}$.

The house required power is obtained from two sources through a smart meter used in the smart house energy management system; the power grid and the proposed electric supplier using renewable energy technologies systems mentioned before. The solar cell and small-scale wind vertical axis turbines energy is stored in battery system and then inverted to $\mathrm{AC}$ power form. The battery can be charged from the solar cell whenever the sun is shining, after the battery reach its full capacity during the day time, the system can supply the generated electric power to the public grid through the smart meter. The suggested home will obtain the electric power from the public grid during the off-peak hours if needed through the smart meter.

To calculate the annual energy performance of the suggested prototype house, ENER-WIN Software for building energy analyses had been used for simulation (ENER-WIN [20]). ENER-WIN is categorized in the following steps (as shown in Fig. 6).

a. First run the program and select the building type as a residential building from the interface window.

b. Select the city for the weather data generation taken Asyut city Egypt as a case study.

c. Draw the building geometry for the ground floor plane.

d. Draw the building geometry for the first floor plane.

e. Define each zone in the plane through the zone processing window.

f. Define each zone description by defining each zone envelope materials cataloging and user profile cataloging; it can be taken as in table 1.

g. Energy summations as Execute the simulation with selected HVAC systems or evaluating passively heated and cooled buildings (no HVAC).

h. System simulations and saving the output results.

Table 1: Building description printed from the run.

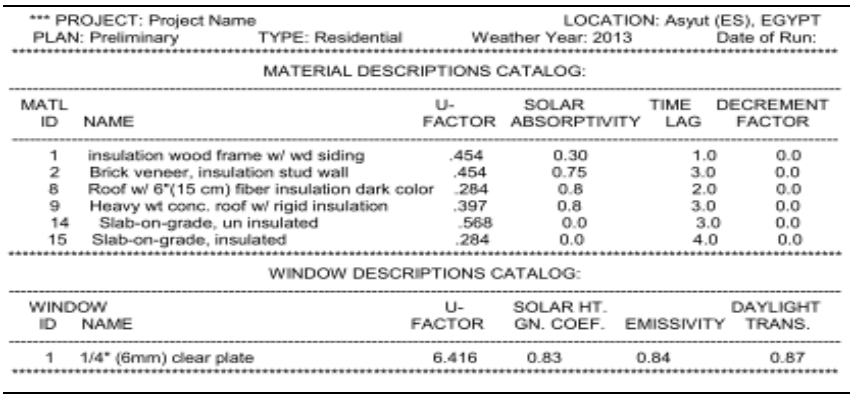




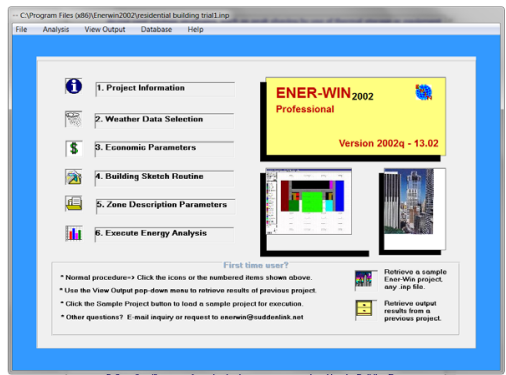

a. ENER-WIN Software interface

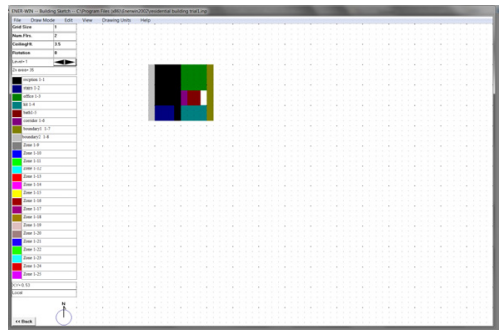

c. Building geometry processing for ground floor

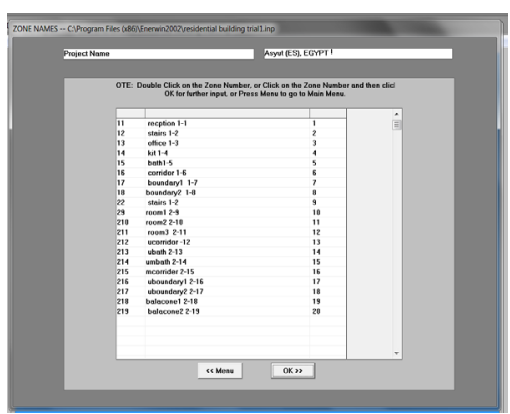

e. Zone processing

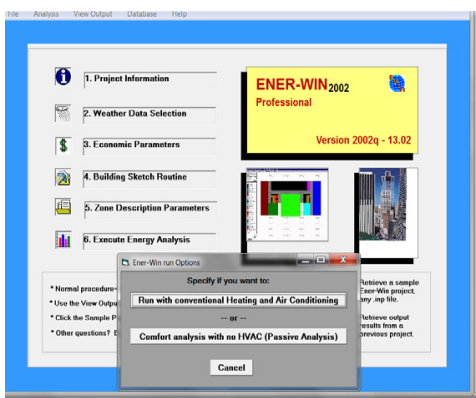

g. Execute the simulation with HVAC or passive

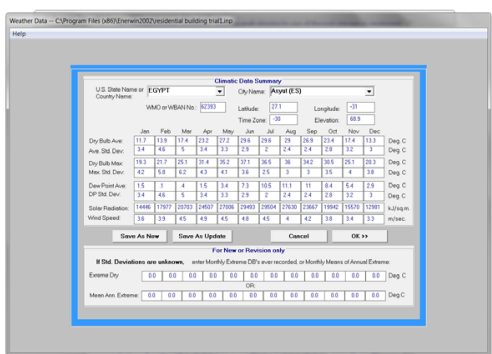

b. weather data generation

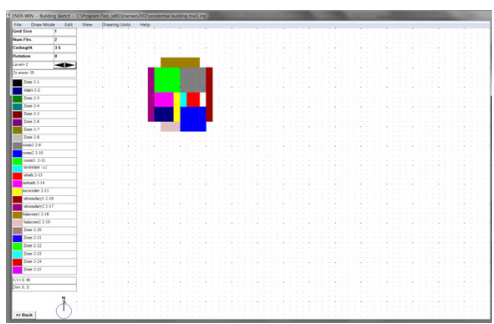

d. Building geometry processing for first floor

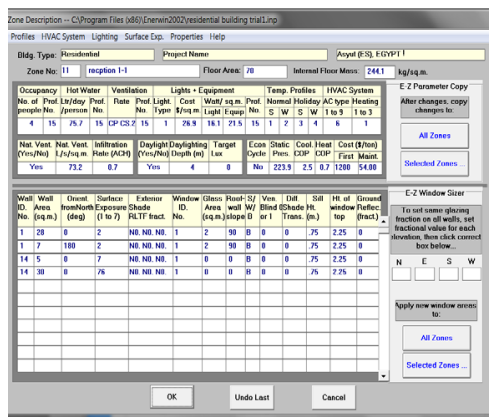

f. Zone description

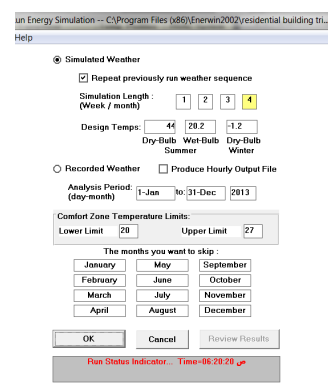

h. Load calculations and system simulations

Figure 6: ENER-WIN software for building energy analyses. 
The obtained results by using ENER-WIN Software for building energy analyses using the active energy HVAC system are shown in Figs. 7, 8 and 9. From these figures clearly seen that the total electric energy consumed was $40283.5 \mathrm{KWh} /$ year with peak electric energy demand $=167.5 \mathrm{KWh} /$ year, also required peak heating power is $11.185 \mathrm{kw}$ on 14 February at $7 \mathrm{am}$, while the peak cooling power is $18.28 \mathrm{kw}$ on 11 June at $6 \mathrm{pm}$.

As illustrated in Fig.7, the maximum need of electric energy occurs in July, corresponding to the maximum cooling load in the same month, whoever this load could be reduced by using passive cooling technology such as underground earth cooling system which will lead to minimize the consumption of electric energy required for the cooling.

The maximum use of space heating energy occurs in Jan (as shown in Fig. 8), to overcome this load can be done by using a passive heating technology as $\mathrm{P} V /$ thermal hybrid solar collectors to decrease both the electric energy needed and heating load. Therefore, the electric energy consumption can be decreased in the cooling energy demand in the hot season (June, July and August), and heating energy demand in the cold season (December, January and February) through using the renewable energy resources on the site with appropriate efficient technologies.

Also the results show that using the smart passive energy techniques, show that the total electric energy consumption is $32509 \mathrm{KWh} /$ year. Correspondence to total peak electric energy demand $=120.3 \mathrm{KWh} /$ year (as shown in Figs. 10 and 11).

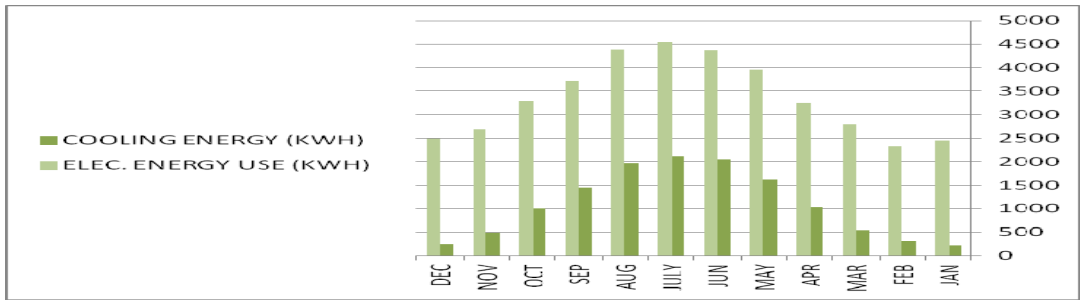

Figure 7: Monthly electric energy and monthly cooling energy consumed by the active energy system.

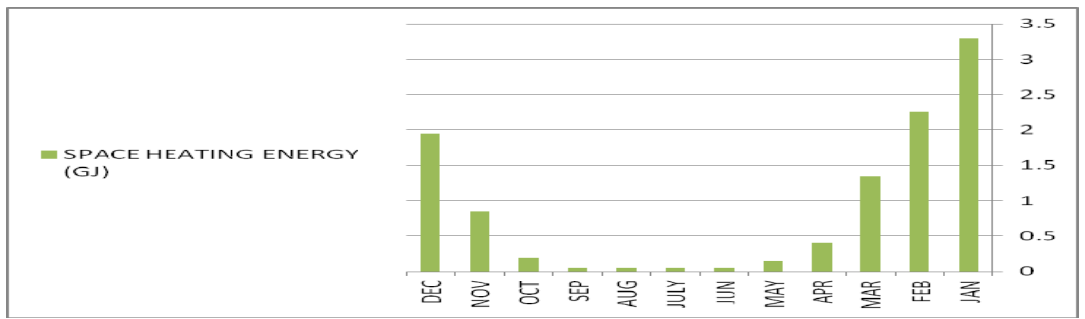

Figure 8: Monthly space heating energy consumed by the active energy system. 


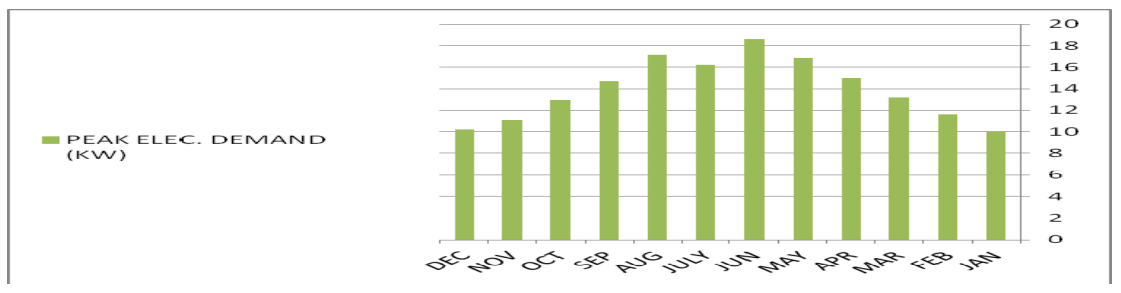

Figure 9: Monthly peak electric energy demand by the active energy system.

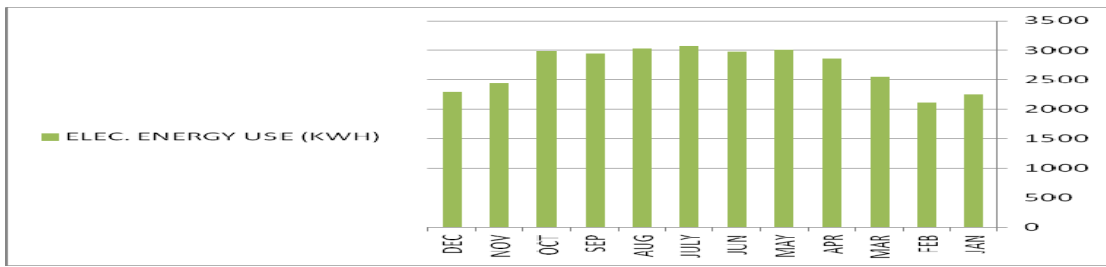

Figure 10: Monthly electric energy consumed by the passive energy system.

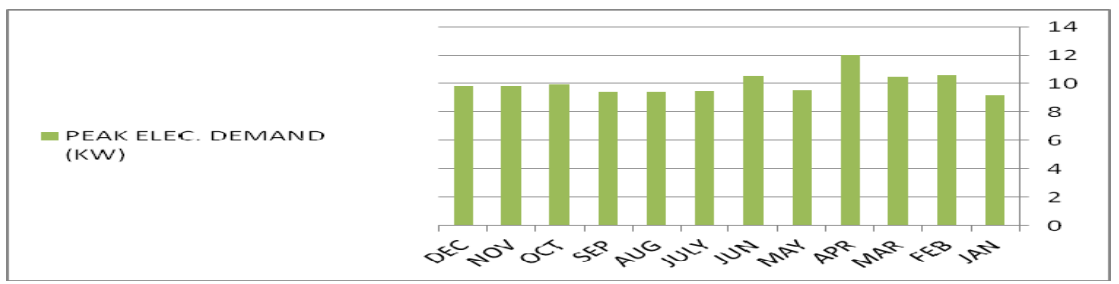

Figure 11: Monthly peak electric energy demand by the active energy system.

\section{Conclusions}

This study presents a proposed design for an energy efficient smart home with renewable energy utilizations in Egyptian desert new cities as well as compared with conventional design homes. This proposed prototype home is designed for a single-family detached house with area of $240 \mathrm{~m}^{2}$ on two floors; each floor has $120 \mathrm{~m}^{2}$, which can be consider as a key for Egypt future in the habitation of people in new towns. The efficient renewable energy technologies planned to provide such home by electricity, heat and supply of cold air need in summer times as follows:

- Electric and heat supply: by using hybrid photovoltaic thermal solar collectors as a source for both electric power and solar thermal energies. While the PV module generates electrical power, in combined with a small-scale vertical axis wind turbines, as a source for electric power. For output heat generated use, a heat exchanger is used to heat water in a storage tank for the 
use of domestic hot water, home heating in winter and optional solar driven cooling systems in summer.

- Cold air supply: by using a combined four cross opening wind catcher with earth air tunnels as a source for fresh cold air supply, assisted by a horizontal and vertical solar shimmy collector for sucking the hot air from the home to be exhausted.

The results obtained from building energy analyses using the active energy HVAC system, the total electric energy consumed was $40283.5 \mathrm{KWh} /$ year with peak electric energy demand $=167.5 \mathrm{KWh} /$ year, also required peak heating power is $11.185 \mathrm{kw}$ on 14 February at $7 \mathrm{am}$, while the peak cooling power is $18.28 \mathrm{kw}$ on 11 June at $6 \mathrm{pm}$. However, using the smart passive energy techniques, show that the total electric energy consumption is $32509 \mathrm{KWh} / \mathrm{year}$. Correspondence to total peak electric energy demand $=120.3 \mathrm{KWh} /$ year. This means that the prototype house could be efficient and save about $20 \%$ of the home energy bill

In the case of the renewable resources not being sufficient or exceeding the needs, the suggested house is equipped with a multiplexer for both renewable power resources and grid power as well as a smart meter for the house energy management. This type of power combination will result in reducing the consumer electrical bill and better manage the peak loads by the electrical utilities.

\section{Acknowledgement}

The author, Mahmoud Mourad, would like to acknowledge the Ministry of Higher Education (MoHE) of Egypt for providing a scholarship to conduct this study as well as the Egypt-Japan University of Science and Technology (EJUST) for offering the facility and tools needed to conduct this work.

\section{References}

[1] Dabaieh, Marwa, Energy efficient design strategies for contemporary vernacular buildings in Egypt, International conference on vernacular heritage and earthen architecture, CIAV, 16-20 October, Portugal, 2013.

[2] The African Development Bank (AfDB), Clean Energy Development in Egypt. African Development Bank (AfDB), Group Temporary Relocation Agency (TRA), Tunisia, 2012.

[3] Janet L. Sawin and Lisa Mastny, World Watch Institute, Prospects of the Renewable Energy Sector in Egypt: Focus on Photovoltaics and Wind Energy, Final Report of Egyptian-German Private Sector Development Programme, Cairo, Egypt, p. 5, 2010.

[4] Mili Majumdar, Energy efficiency in architecture: An overview of design concepts and architectural interventions, 2001. http://bookstore.teriin.org /docs/books/Introduction\%20energy\%20eff\%20biuldings.pdf 
[5] Shady Attia, Arnaud Evrard, Elisabeth Gratia, Development of benchmark models for the Egyptian residential buildings sector, Applied Energy, 94, pp. 270-284, 2012.

[6] George B. Hanna, Energy Efficient Residential Building Code for Arab Countries, Tenth International Conference for Enhanced Building Operations, Kuwait, October 26-28, 2010.

[7] Energy Efficiency Residential Building Code, Ministry of Housing, HBRC, Egypt, 2005.

[8] Egyptian Green Building Council, http://egypt-gbc.org/

[9] New and Renewable Energy Authority (NREA), Ministry of Electricity and Energy, Annual Report, 2010/2011.

[10] George B. Hanna, Green Energy and Green Buildings in Egypt, International Journal of Engineering Research and Applications (IJERA) V, 3, Issue 4, pp. 466-470, 2013.

[11] Climate Change Policy Headquarters, Yokohama Smart City Project (YSCP), http://siteresources.worldbank.org/INTURBANDEVELOPMENT /Resources/3363871296405826983/7699103-1296623042596/4_2, Okazaki (Yokohama)2.pdf

[12] Mario J. Kofler, Christian Reinisch, Wolfgang Kastner, A semantic representation of energy-related information in future smart homes, Energy and Buildings, 47, pp. 169-179, 2012.

[13] R. Al-Ali, Ayman El-Hag, Mujib Bahadiri, Mustafa Harbaji, Yousef Ali El Haj, Smart Home Renewable Energy Management System, Energy Procedia, 12, pp. 120-126, 2011.

[14] Tjerk H. Reijenga, PV in Architecture. Handbook of Photovoltaic Science and Engineering, John Wiley and Sons, Ltd, pp. 1005-1042, 2003.

[15] Jorge M. Huacuz and Lalith Gunaratne, Photovoltaic and Development. Handbook of Photovoltaic Science and Engineering, John Wiley and Sons, Ltd, pp. 1043-1071, 2003.

[16] www.tessolarwater.com, TESZEUS ${ }^{\circledR}$ Photovoltaic-Thermal Hybrid Solar Collector.

[17] Tamer Abdel Aziz, Osama Elmassah. Could renewable energy affect the form of the city? "Wind energy as a special parameter", Energy Procedia, 8, pp. 276-290, 2012.

[18] Bioclimatic Architecture, http://litteramedia.wordpress.com/2012/12/14 /bioclimaticarchitecture/2009-isla-palenque-bio-climatic-studies1/

[19] wordpress.com http://gees7.files.wordpress.com/passive-cooling-techniques

[20] ENER-WIN. - the MS-Windows version of energy simulation software package under a DOE-sponsored project. http://enerwin.com or http://enerwin.org 